\title{
Characterization and Antimicrobial Activities of a Metabolite from a New Streptomyces Species from Bangladeshi Soil
}

\author{
M. A. M. Akhand, M. A. A. Al-Bari, M. A. Islam and Proma Khondkar ${ }^{1}$ \\ Pharmaceutical Microbiology Research Laboratory, Department of Pharmacy, Rajshahi University, \\ Rajshahi-6205, Bangladesh
}

Received 17 August 2009, accepted in revised form 10 November 2009

\begin{abstract}
A new actinomycete strain was isolated from Western part of Bangladesh and identified as a new Streptomyces species on the basis of its morphological, biochemical, cultural characteristics and 16S rRNA data. The present paper describes the isolation and characterization of compound $\mathbf{1}$ from this new Streptomyces species with the help of various chemical and spectroscopic methods. Antimicrobial activity of compound $\mathbf{1}$ was tested by disc diffusion assay method and compared with that of standard antibiotics (Kanamycin for antibacterial activity and Nystatin for antifungal activity). The compound has been found to exhibit moderate to strong antimicrobial activity against the test organisms. Cytotoxicity of the compound 1 and the pet. ether extract of Czapek Dox (alkaline) broth of Streptomyces species was evaluated in brine shrimp bioassay with $\mathrm{LC}_{50}$ values of $23.85 \mu \mathrm{g} / \mathrm{ml}(\mathrm{ppm})$ and $19.95 \mu \mathrm{g} / \mathrm{ml}$ (ppm), respectively.
\end{abstract}

Keywords: Streptomyces; Antimicrobial activity; Cytotoxicity.

(c) 2010 JSR Publications. ISSN: 2070-0237 (Print); 2070-0245 (Online). All rights reserved.

DOI: $10.3329 /$ jsr.v2i1.3079 J. Sci. Res. 2 (1), 178-185 (2010)

\section{Introduction}

Antibiotic resistant pathogens have been widely and continuously reported. In consequence, novel antibiotics have been isolated from various microorganisms and search for new antibiotics against pathogenic bacteria and fungi are still continued. Soil bacteria and fungi have played a significant role in antibiotic discovery. Streptomyces species have been always a source of thousands of bioactive compounds and screening programs have shown that secondary metabolites can be isolated which bind to active sites of enzyme organelles and receptors [1, 2]. Streptomycetes are rich source of bioactive compounds, notably antibiotics, enzyme inhibitors and pharmacologically active agents [3]. As a result, secondary metabolites produced by Streptomyces have been the primary source of antibiotics and more recently, are used as herbicides, anticancer drugs,

\footnotetext{
${ }^{1}$ Corresponding author: proma_khondkar@yahoo.co.uk
} 
immunoregulators and antiparasitic compounds [4]. Recently, research provides a basis for the development of new approaches to combat human diseases [5]. Infectious diseases are leading health problems with high morbidity and mortality in the developing countries [6, 7]. The first systemic search for antibiotics, made by Gratia and Dath around 1924 [8], resulted in the discovery of actinomycetin from a strain of Actinomycetes. At present, 4,000 antibiotic substances obtained from bacteria and fungi have been applied in medicine, out of which about $75 \%$ are produced from Gram-positive actinomycetes bacteria such as Streptomyces sp. [9, 10]. Most of the antibiotics are extracellularsecondary metabolites which are normally secreted in culture media and serve as intermediates from primary metabolisms as precursors for their biosynthetic process [10]. As part of our ongoing research of microbial metabolites [11, 12], we isolated a new strain of Streptomyces species [13] from a soil sample collected in the region of Kushtia. We, herein, report the isolation of compound $\mathbf{1}$ from this new species as well as the antimicrobial and cytotoxic activities of this compound and crude pet ether extract of Czapek Dox (alkaline) broth of this new species.

\section{Materials and methods}

\subsection{Collection and identification of organism}

The organism was isolated from a soil sample collected from Kushtia, Bangladesh at the depth of $0.75 \mathrm{~m}$ during the month of september 2003, using crowded plate technique [14]. The 16S rDNA sequence generated in this work was compared with the 16S rDNA sequences of other organisms retrieved from the EMBL/GenBank database. The nearest is being Streptomyces parpurascens, with 99.3\% nucleotide similarity. In addition, the morphological, physiological and biochemical properties of the present isolate was also different from Streptomyces parpurascens [13]. On the basis of morphological, physiological, biochemical and sequencing of 16S rDNA studies, the organism was identified as a novel Streptomyces species and named as Streptomyces lalonnensis [13].

\subsection{Fermentation}

The strain was grown on modified Czapek Dox (alkaline) agar slant at $37.5^{\circ} \mathrm{C}$ for 10 days. Spores were collected from a slant culture with $10 \mathrm{ml}$ of the same medium (broth). Cultivation of the strain was made by transferring $1 \mathrm{ml}$ (ca. $10^{8}$ cells $/ \mathrm{ml}$ ) of the spore suspension and was incubated at $37.5^{\circ} \mathrm{C}$ (at $250 \mathrm{rpm}$ ) for ten days in $500 \mathrm{ml}$ Erlenmeyer flasks each containing $100 \mathrm{ml}$ of antibiotic medium consisted of $2 \%$ sucrose, $0.25 \%$ yeast extract, $0.1 \% \mathrm{~K}_{2} \mathrm{HPO}_{4}, 0.05 \% \mathrm{MgSO}_{4} .7 \mathrm{H}_{2} \mathrm{O}, 0.001 \% \mathrm{FeSO}_{4} 7 \mathrm{H}_{2} \mathrm{O}$ and $0.002 \%$ $\mathrm{NaCl}$.

\subsection{Extraction and isolation}

The culture broth $(50 \times 200 \mathrm{ml})$ of $S$. lalonnensis was partitioned with pet ether and ethyl acetate $(50 \times 60 \mathrm{ml})$ respectively and concentrated to dryness by using a rotary evaporator 
under vacuum at $40^{\circ} \mathrm{C}$. We could not purify the ethyl acetate extract due to limited facilities and scarcity of time. Preparative TLC of the pet ether soluble part (1.25 gm) over Si gel $60 \mathrm{PF}_{254}$ gel using mobile phase, pet. ether:chloroform (10:1) yielded compound 1 (12 mg purple color powder, mp. $110-120^{\circ} \mathrm{C}$ ).

\subsection{Antibacterial and antifungal screening}

Both antibacterial and antifungal activities of compound $\mathbf{1}$ and pet ether extract were observed by disc diffusion assay $[15,16]$. A total of five Gram positive and nine Gram negative bacteria were used in this antimicrobial screening. Compound $\mathbf{1}$ and pet. ether extract $(100 \mu \mathrm{g} / \mathrm{disc}$ and $30 \mu \mathrm{g} / \mathrm{disc})$ were prepared by dissolving with pet. ether. To compare the antibacterial activity, kanamycin (30 $\mathrm{g} / \mathrm{disc})$ was used as standard antibiotic. As a negative control, a blank disc impregnated with solvent followed by drying off was used. The antifungal activity of the compound $\mathbf{1}$ and pet ether were tested against eight pathogenic fungi at a concentration of $200 \mu \mathrm{g} /$ disc. Potato dextrose agar (PDA) media was used for this purpose. The activity was determined after 72 hours of incubation at room temperature $\left(37^{\circ} \mathrm{C}\right)$. Nystatin was used as standard at a concentration of $20 \mu \mathrm{g} / \mathrm{disc}$.

\subsection{Minimum inhibitory concentration (MIC) assay}

The minimum inhibitory concentrations (MIC) were determined by serial dilution technique [17] in the presence of standard Kanamycin (for bacteria) and Nystatin (for fungi). Bacterial and fungal inocula were prepared at $5 \times 10^{6}-5 \times 10^{7} \mathrm{cfu} / \mathrm{ml}$. Final adjustment were made using optical density measurement for bacteria (absorbance 0.05 at a wavelength of $660 \mathrm{~nm}$ ).

\subsection{Cytotoxicity screening}

The eggs of the brine shrimp, Artemia salina, were collected from an aquarium shop (Dhaka, Bangladesh) and hatched for $48 \mathrm{hr}$ to mature shrimp called nauplii. [18, 19] The test samples (extracts and compound) were prepared by dissolving them in DMSO (not more than $50 \mathrm{ml}$ in $5 \mathrm{ml}$ solution) plus sea water $(3.8 \% \mathrm{NaCl}$ in water) to attain concentrations- $2.5 \mathrm{mg} / \mathrm{ml}, 5 \mathrm{mg} / \mathrm{ml}, 10 \mathrm{mg} / \mathrm{ml}, 20 \mathrm{mg} / \mathrm{ml}, 40 \mathrm{mg} / \mathrm{ml}$ and $80 \mathrm{mg} / \mathrm{ml}$. A vial containing $50 \mathrm{ml}$ DMSO diluted to $5 \mathrm{ml}$ was used as a control. Then 20 matured shrimps were applied to each of all experimental vials and control vial. The number of the nauplii that died after $24 \mathrm{hr}$ was counted. The findings were presented graphically by plotting log of concentration versus percentage of mortality of nauplii from which $\mathrm{LC}_{50}$ was determined by extrapolation. The assay was performed in duplicate and the result was calculated as an average of two determinations. The cytotoxicity of the compound $\mathbf{1}$ was compared with the standard gallic acid and also with the anticancer agent bleomycin. 


\section{Results and discussion}

\subsection{Characterization of the compound 1}

The compound 1 with $\mathrm{R}_{\mathrm{f}}$ value 0.92 ( $\mathrm{Si}$ gel $\mathrm{GF}_{254}$, solvent system, pet. ether: chloroform= 10:1) was isolated from pet. ether extract of the metabolites of a new Streptomyces species and was obtained as purple powders with mp. $110-120^{\circ} \mathrm{C}$. The compound was found to be odorless and it appeared as a yellowish spot on TLC plate when viewed under UV light (254 nm).

The compound $\mathbf{1}$ was assigned on the basis of a series of 1D and 2D NMR data (Table 1) and mass spectra. The molecular formula of compound $\mathbf{1}$ was established as $\mathrm{C}_{14} \mathrm{H}_{23} \mathrm{NO}_{3}$ from a molecular ion peak at 253 in the mass spectra. The ${ }^{1} \mathrm{H}-\mathrm{NMR}$ spectrum (500 MHz, $\left.\mathrm{CDCl}_{3}\right)$ showed two doublet of doublet at $4.17(J=1.53)$ and $4.32(J=1.35)$, a multiplet at 5.26. In COSY spectrum, these protons showed interaction among themselves. The ${ }^{13} \mathrm{C}-$ NMR spectrum (125 MHz, $\left.\mathrm{CDCl}_{3}\right)$ showed one methylene $\left(\delta_{\mathrm{C}} 62.3\right.$ directly connected to $\delta_{\mathrm{H}} 4.32$ and $\delta_{\mathrm{H}} 4.17$ from HSQC) and one methine ( $\delta_{\mathrm{C}} 69.1$ directly connected to $\delta_{\mathrm{H}} 5.26$ from HSQC) peaks. In the HMBC experiment, the proton at $\delta 5.26$ showed ${ }^{2} J$ correlation to the methylene carbons $\delta_{\mathrm{C}} 62.3$ while protons at 4.17 and 4.32 showed both direct and long range $\left({ }^{3} J\right)$ correlation to the same carbon $\left(\delta_{C} 62.3\right)$. This means that the carbon chemical shift at 62.3 must be accounted from two methylene carbons corresponding to protons at 4.17 and 4.32 . The latter protons showed ${ }^{2} J$ correlation to methine at $\delta 69.1$ and ${ }^{3} \mathrm{~J}$ correlation to a carbonyl at 173.5. From this finding the partial structure of the compound can be drawn as

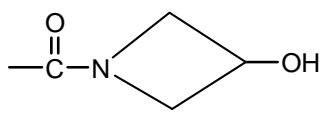

The ${ }^{1} \mathrm{H}$-NMR spectrum showed a series of methylene peaks. Among these peaks, the multiplet at $1.62\left(\delta_{\mathrm{C}} 25.1\right.$ from HSQC) showed ${ }^{2} J$ connectivity to carbons at $34.2\left(\delta_{\mathrm{H}} 2.32\right.$ from HSQC) and 29.3 ( $\delta_{\mathrm{H}} 1.29$ from HSQC) and ${ }^{3} J$ correlation to carbonyl at 173.5 . So this methylene was assigned as H-3 starting from carbonyl at 173.5 (C-1). H-3 showed direct connectivity to $\mathrm{H}-2$ and $\mathrm{H}-4$ in ${ }^{1} \mathrm{H}-{ }^{1} \mathrm{H}$ COSY experiment. Thus the above partial structure can be extended to

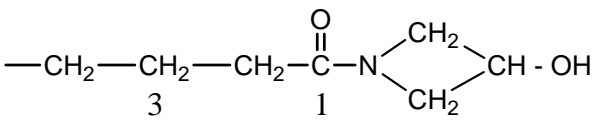

The ${ }^{13} \mathrm{C}-\mathrm{NMR}$ spectrum showed two olefinic methine carbons at 129.9 and 130.2. Both of these carbons correspond to a multiplet signal at 5.34 in ${ }^{1} \mathrm{H}-\mathrm{NMR}$ spectrum which in turn showed connectivity to carbonyl at 173.4 and methylene at $27.4\left(\delta_{\mathrm{H}} 2.02\right.$ from HSQC) and $29.9\left(\delta_{\mathrm{H}} 1.28\right.$ from HSQC). A methyl signal appeared as triplet at 0.89 in ${ }^{1} \mathrm{H}-$ NMR spectrum exhibited HMBC correlations to methylene carbons at $22.9\left(\delta_{\mathrm{H}} 1.30\right.$ from HSQC) and 27.4 ( $\delta_{\mathrm{H}} 2.02$ from HSQC). The methylene protons at 2.02 was connected to 
olefinic protons $\left(\delta_{\mathrm{H}}\right.$ 5.34) and methylene at 1.30 in COSY experiment. The latter methylene was connected to methyl signal. So the structure of this part of the molecule can be drawn as

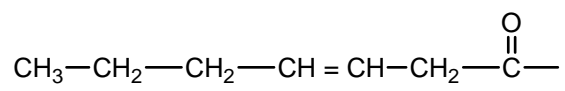

So combination of these two partial structures gives the complete structure of $\mathbf{1}$. Thus compound $\mathbf{1}$ is identified as (E)-1-(3-hydroxyazetidin-1-yl) undec-7-ene-1,5-dione (Figure 1). To our best knowledge this is a new compound.

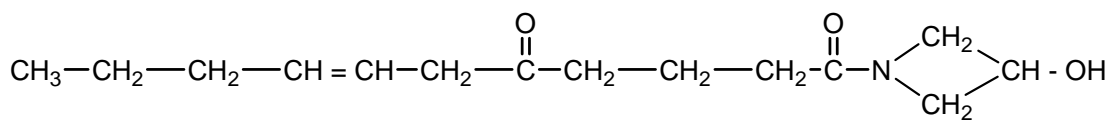

Fig. 1. Structure of compound 1.

Table 1. ${ }^{1} \mathrm{H}(500 \mathrm{MHz}),{ }^{13} \mathrm{C}(125 \mathrm{MHz})$ and ${ }^{1} \mathrm{H}-{ }^{13} \mathrm{C} \mathrm{HMBC}(500 \mathrm{MHz})$ data of the compound $\mathbf{1}$ in $\mathrm{CDCl}_{3}$.

\begin{tabular}{lllll}
\hline Positions & ${ }^{1} \mathrm{H}$ & ${ }^{13} \mathrm{C}$ & \multicolumn{2}{c}{ HMBC Key Correlation } \\
& $\delta_{\mathrm{H}}$ & $\delta_{\mathrm{C}}$ & ${ }^{2} J$ & \multicolumn{2}{c}{${ }^{3}$} \\
1 & - & 173.5 & - & - \\
2 & $2.32, m$ & 34.2 & $173.5(\mathrm{CO}), 25.1$ & $29.3\left(\mathrm{CH}_{2}\right)$ \\
3 & $1.62, m$ & 25.1 & $34.2\left(\mathrm{CH}_{2}\right), 29.3\left(\mathrm{CH}_{2}\right)$ & $173.5(\mathrm{CO})$ \\
4 & $1.29, m$ & 29.3 & $\mathrm{NS}$ & $\mathrm{NS}$ \\
5 & - & 173.4 & - & - \\
6 & $1.28, m$ & 29.9 & - & - \\
7,8 & $5.34, m$ & $129.9,130.2$ & $27.4\left(\mathrm{CH}_{2}\right), 29.9\left(\mathrm{CH}_{2}\right)$ & 173.4 \\
9 & $2.02, m$ & 27.4 & $130.2\left(\mathrm{CH}^{2}\right)$ & - \\
10 & $1.30, m$ & 22.9 & $12.4\left(\mathrm{CH}_{3}\right)$ & - \\
11 & $0.89, t, J=1.74$ & 12.4 & $22.9\left(\mathrm{CH}_{2}\right)$ & $27.4\left(\mathrm{CH}_{2}\right)$ \\
$2^{\prime}, 4^{\prime}$ & $4.17, d d, J=1.53$ & 62.3 & $69.1\left(\mathrm{CH}^{\prime}\right)$ & $62.3\left(\mathrm{CH}_{2}\right), 173.5(\mathrm{CO})$ \\
& $4.32, d d, J=1.35$ & & & \\
$3^{\prime}$ & $5.26, m$ & 69.1 & $62.3\left(\mathrm{CH}_{2}\right)$ & \\
\hline
\end{tabular}

\subsection{Antibacterial activity}

Both the compound $\mathbf{1}$ and pet. ether extract showed remarkable biocidal activity (100 $\mu \mathrm{g} /$ disc) against the tested Gram positive and Gram negative bacteria (Table 2). In case of some pathogenic bacteria, pet. ether extract was more active than compound $\mathbf{1}$ which indicated the presence of more bioactive compounds in the extract. When the concentration was $30 \mu \mathrm{g} / \mathrm{disc}$, none of the test materials showed a remarkable antibacterial activity against the tested bacteria in comparison with the standard kanamycin. In the 
present investigation we found that, both the compound and extract showed comparatively better antibacterial activity against the Gram positive bacteria than the Gram negative bacteria.

Table 2. Antibacterial activity of pet. ether extract, compound $\mathbf{1}$ and Kanamycin.

\begin{tabular}{|c|c|c|c|c|c|c|}
\hline \multirow[t]{2}{*}{ Test organisms } & \multirow[t]{2}{*}{ Strain No. } & \multicolumn{5}{|c|}{ Diameter of zone of inhibition (mm) } \\
\hline & & $\begin{array}{l}\text { pet. ether } \\
\text { extract } \\
30 \mu \mathrm{g} / \text { disc }\end{array}$ & $\begin{array}{l}\text { pet. ether } \\
\text { extract } \\
100 \mu \mathrm{g} / \mathrm{disc}\end{array}$ & $\begin{array}{l}\text { comp.1 } \\
30 \mu \mathrm{g} / \text { disc }\end{array}$ & $\begin{array}{l}\text { comp.1 } \\
100 \mu \mathrm{g} / \text { disc }\end{array}$ & $\begin{array}{l}\text { Kanamycin } \\
30 \mu \mathrm{g} / \text { disc }\end{array}$ \\
\hline \multicolumn{7}{|l|}{ Gram positive } \\
\hline Sarcina lutea & QL-166 & 11 & 20 & 13 & 22 & 20 \\
\hline Bacillus megaterium & QL-38 & 10 & 20 & 11 & 22 & 25 \\
\hline Bacillus subtilis & QL-40 & 10 & 24 & 11 & 23 & 26 \\
\hline $\begin{array}{l}\text { Streptococcus- } \beta \text { - } \\
\text { haemolyticus }\end{array}$ & CRL & 12 & 21 & 12 & 21 & 24 \\
\hline Staphylococcus aureus & ATCC-259233 & 11 & 19 & 13 & 21 & 22 \\
\hline \multicolumn{7}{|l|}{ Gram negative } \\
\hline Salmonella typhi & - & 13 & 24 & 12 & 19 & 20 \\
\hline Shigella dysenteriae & AL-35587 & 15 & 30 & 13 & 20 & 22 \\
\hline Shigella boydii & AL-17313 & 14 & 23 & 12 & 20 & 24 \\
\hline Shigella sonnei & AJ-8992 & 13 & 20 & 13 & 25 & 23 \\
\hline Shigella flexneri & AL-30372 & 10 & 21 & 13 & 27 & 25 \\
\hline Shigella shiga & ATCC-26107 & 11 & 24 & 14 & 24 & 24 \\
\hline Escherichia coli & FPFC-1407 & 9 & 16 & 14 & 20 & 25 \\
\hline Pseudomonas aeruginosa & CRL & 12 & 25 & 11 & 20 & 23 \\
\hline Klebsiella species & - & 12 & 23 & 10 & 18 & 24 \\
\hline
\end{tabular}

\subsection{Antifungal activity}

The antifungal activities of the compound $\mathbf{1}$ and pet ether extract were determined at the concentration of $200 \mu \mathrm{g} /$ disc against pathogenic fungi. It was found that the pet ether extract had greater activity than the compound $\mathbf{1}$ against all of the pathogenic fungi (Table 3) which may be due to the presence of more bioactive compounds in the crude extract.

Table 3. Antifungal activity of pet. ether extract, compound $\mathbf{1}$ and Nystatin.

\begin{tabular}{lccc}
\hline \multirow{2}{*}{ Test Organism } & \multicolumn{2}{c}{ Diameter of zone of inhibition (in mm) } \\
\cline { 2 - 4 } & $\begin{array}{c}\text { pet. ether extract } \\
200 \mu \mathrm{g} / \mathrm{disc}\end{array}$ & $\begin{array}{c}\text { comp.1 } \\
200 \mu \mathrm{g} / \mathrm{disc}\end{array}$ & $\begin{array}{c}\text { Nystatin } \\
\text { (20/disc }\end{array}$ \\
\hline Candida albicans & 20 & 11 & 22 \\
Aspergillus fumigatus & 17 & 8 & 19 \\
Aspergillus flavus & 23 & 14 & 23 \\
Aspergillus niger & 22 & 13 & 24 \\
Epidermophyton floccosum & 18 & 9 & 21 \\
Trichoderma species & 22 & - & 30 \\
Fusarium species & 19 & 8 & 26 \\
Bipolavis species & 20 & 8 & 24 \\
\hline
\end{tabular}




\subsection{Minimum inhibitory concentration (MIC)}

The MIC values of the compound 1 and pet. ether extract against Bacillus subtilis, Staphylococcus aureus, Salmonella typhi, Shigella dysenteriae, Escherichia coli, Streptococcus $\beta$ haemolyticus, Candida albicans, Aspergillus flavus and Aspergillus niger were shown in Table 4. The MIC values of the compound $\mathbf{1}$ and pet. ether against the tested microorganisms were maximum which indicated that the compound $\mathbf{1}$ were less active against the bacteria and the fungus. For compound 1 the MIC values were 64,128, 128, 128, 64, 128, 64, 128 and $64 \mu \mathrm{g} / \mathrm{ml}$, respectively against the organisms; whereas the pet. ether extract showed MIC values between 32-128 $\mu \mathrm{g} / \mathrm{ml}$ which was indicative of their potent antibacterial properties than the compound $\mathbf{1}$.

Table 4. Results of MIC values (in $\mu \mathrm{g} / \mathrm{ml}$ ).

\begin{tabular}{lcccc}
\hline Test organisms & comp. 1 & pet. ether extract & Kanamycin & Nystatin \\
\hline Bacillus subtilis & 64 & 32 & 2 & - \\
Staphylococcus aureus & 128 & 64 & 8 & - \\
Salmonella typhi & 128 & 128 & 4 & - \\
Shigella dysenteriae & 128 & 64 & 2 & - \\
Escherchtia. coli & 64 & 32 & 4 & - \\
Streptococcus $\beta$-hemolyticus & 128 & 64 & - & 4 \\
Candida albicans & 64 & 64 & - & 4 \\
Aspergillus flavus & 128 & 64 & - & 4 \\
Aspergillus niger & 64 & 32 & - & 8 \\
\hline
\end{tabular}

\subsection{Cytotoxicity assay}

The mortality rate of brine shrimp nauplii was found to increase with increasing the concentration of complexes. Table 5 summarizes the $\mathrm{LC}_{50}$ values of the pet ether extract

Table 5. Cytotoxic effect of compound 1, pet.ether extract and standard bleomycin and gallic acid.

\begin{tabular}{llllll}
\hline Test samples & $\begin{array}{l}\mathrm{LC}_{50} \\
(\mathrm{ppm})\end{array}$ & \multicolumn{2}{l}{$\begin{array}{l}\text { 95\% confidence limit }(\mathrm{ppm}) \\
\text { lower }\end{array}$} & $\begin{array}{l}\text { Regression } \\
\text { equation }\end{array}$ & $\chi^{2}(\mathrm{df})$ \\
\hline Compound $\mathbf{1}$ & 23.85 & 2.08 & 6.02 & $Y=3.98+1.85 X$ & $3.38(2)$ \\
Pet. ether extract & 19.95 & 4.15 & 10.15 & $Y=3.17+2.27 X$ & $0.35(2)$ \\
Standard bleomycin & 0.41 & 0.27 & 0.62 & $Y=3.16+2.98 X$ & $0.62(2)$ \\
Gallic acid & 4.53 & 3.33 & 6.15 & $Y=3.93+1.62 X$ & $1.25(2)$ \\
\hline
\end{tabular}


and the compound 1. The values were found at $19.95 \mu \mathrm{g} / \mathrm{ml}(\mathrm{ppm})$ and $23.85 \mu \mathrm{g} / \mathrm{ml}$ (ppm), respectively. The standard anticancer drug bleomycin and gallic acid gave $\mathrm{LC}_{50}$ value at $0.41 \mu \mathrm{g} / \mathrm{ml}(\mathrm{ppm})$ and $4.53 \mu \mathrm{g} / \mathrm{ml}(\mathrm{ppm})$, respectively.

\section{Acknowledgement}

The authors are indebted to Professor Isomaro Yamaguchi, University of Tokyo, Japan for sending the spectral data essential for structure determination.

\section{References}

1. D. H. Williams, M. J. Stone, P. R. Hauck and S.K. Rahman, J. Nat. Prod. 52, 1189 (1989). doi:10.1021/np50066a001

2. D. H. Williams, Stone, M .J. Mortishire, R. J. Smith and P. R. Hauck, J. Biochem. Pharmaco. 40, 27 (1990). doi:10.1016/0006-2952(90)90174-J

3. J. Berdy, Biotechnologia 7-8, 13 (1995).

4. C. J. Thompson and S. H. Bialphos, (In: L. C. Vining and C Stuttard, editors) Genetics and Biochemistry of antibiotic production, Butterworth Heinemann Bio/Technology, Oxford, 1995). pp. 197-222.

5. W. R. Jack and A. R. Gennaro, Remington's Pharmaceutical Sciences, $8^{\text {th }}$ Edition (Mack Publishing Company, Easton Pennsylvania, 1990).

6. R. E. Black, K. D. Brown, S. Becker and M. Yunus, Am. J. Epidemiol. 115, 305 (1982).

7. J. A. Walsh and K. S. Warren, New Engl. J. Med. 301, 967 (1979).

8. L. J. Hanka and A.Dietz, J. Antimicrob. Agents Chemother. 3, 425 (1973).

9. J. Dienstag and H. C. Nue, J. Antimicrob. Agents Chemother. 1, 41 (1972).

10. A. Argoudelis, D. L. Baczyneky, M. T. Duo, A. l. Laborde, O. K. Sebek, S. K. Truesdel and F. B. Shilliday, J. Antibio., 40, 750 (1987).

11. A. Jabbar, A. P. Shresta, C. M. Hasan, and M. A. Rashid, Nat. Prod. Sci. 5, 162 (1999).

12. M. S. Hossain, M. A. Hossain, M. M. Rahman, M. A. Mondol, M. S. A. Bhuiyan, A. I. Gray, M. I. Flores, and M. A. Rashid, Phytochem. 65, 2147 (2004). doi:10.1016/j.phytochem.2004.10.001

13. M. A. A. Akhanda, M.Pharm. Thesis, Rajshahi University, Rajshahi, Bangladesh, 2004.

14. S. M. Hammond and P. A. Lambert, Antimicrobial Action, (Edward Arnold Ltd. London, 1978).

15. A. W. Bauer, W. M. M. Kirby, J. C. Sherris, and M. Turck, Am. J. Clin. Pathol. 44, 493 (1966).

16. A. L. Barry, Principle and Practice of Microbiology (Lea and Fabager, Philadelphia, 1976).

17. R. Reiner, Antibiotics: An Introduction (Roche Scientific Service, Switzerland, 1982).

18. J. L. Mclaughlin, Bioassays for discovery of Antitumor and Antiviral Agent from Natural Sources Proceedings of NIH workshop, Bethesda, 18, 1988.

19. B. N. Meyer, N. R. Ferringni, J. E. Puam, L. B. S. Laeob, D. E. Nichois, and J. L. Mclaughlin, Planta Med. 45, 31 (1982). doi:10.1055/s-2007-971236 